\title{
TRANSITIVE AS FUNCTIONAL MARK OF THE TOURISTIC LOCATION OF REPUBLIC OF MACEDONIA AS PRECONDITION FOR DEVELOPING TRANSIT TOURISM
}

DOI: http://dx.doi.org/10.18509/GBP.2015.58 UDC: 338.48-44(497.7-83),,1990-2001“6

\author{
Ass. Prof. Ph.D. Tanja Angelkova Petkova \\ M.Sc. Cvetanka Ristova \\ Goce Delcev" University - Stip, Faculty of tourism and business logistics - Gevgelija, Republic \\ of Macedonia
}

\begin{abstract}
The subject of this paper is the development of the Republic of Macedonia as a transit tourist destination. That is a characteristic which is primarily owned due to its tourist geographical location where with the assumption of the role as the biggest traffic crossroad in the Balkan and Europe, first of all thanks to her transitive, which is whole will bring additionally in the development of transit tourism. For that purpose are determined her functional marks as a country with a central location at the Balkan. Next, is presented the transit tourism as a concept with his potentials and opportunities as the main focus of this paper for the development of the Republic of Macedonia and therefore the benefit from the same.
\end{abstract}

Keywords: tourist development, tourist destination, transit area.

\section{INTRODUCTION}

Tourists and leisure needs along with more free time have become a valuable component in everyday life of the people. The changes that affected people's way of living resulted more free time, and more ways of how that free time is used. Seeking new places to visit, new experiences and activities, the search for emotional accomplishment resulted of the development of selective types of tourism. Selective tourism today is defined as a type of tourism that strives for answering and indulging the needs of the tourists. According to the analysis of Pančič Kombol ${ }^{[54]}$ the selective type of tourism can be understood a generic term which includes all forms of tourism which has recently been developing more clearly exhibit characteristics that are different from mass tourism.

Probably there isn't any other country in the world that on so small geographical location consists large number of natural and cultural heritage and still is achieving weak results in the field of tourism ${ }^{[55]}$. The territory of the Republic of Macedonia has all the characteristics for developing of tourism, which will allow the formation of the selective types of tourism. This paper will analyze the position of the Republic of Macedonia at the touristic market along with the selective types, and present the need of a new type of possibility starting from the basic, her geographical location.

\footnotetext{
[54] Pančič Kombol, Tonka. Selective tourism. TMCP Sagena d.o.o Matulji, 2000

${ }^{[55]}$ Tuntev, Z. Possibility of development selective types of tourism in Republic of Macedonia. Institution of geography, Magazine Tourism, num. 5, pp 32, 2001
} 


\section{TOURISM IN REPUBLIC OF MACEDONIA (CURRENT POSITION AND ANALYSIS)}

The problem with the internal political and economic situation, blockage of all economic flows with Republic of Greece, irrational problems with the name of our country, military actions and permanent political instability forced by the collapse of Yugoslavia ${ }^{[56]}$ for a long time has been an excuse for the poor placement of the Republic of Macedonia at the tourist market. Republic of Macedonia has detect decreasing of the tourists arrival and nights spent from 1990 to 1992 for over 39.9\% due to the collapse of Yugoslavia, which continued with variable placement until 2001, where in 2001 as an effect from the military conflict and the Kosovo refugee crisis in the tourist arrival and nights spent have reduced to 333.308 arrivals and 1.254.582 nights spent, which is $47 \%$ decreasing of tourists arrival and $48.4 \%$ nights spent from the previous year.

From 2002 until now, the Republic of Macedonia has developed a numerous strategies for developing the tourism, accentuating the selective types of tourism and placing herself on the tourist market. Inevitable if the fact that Republic of Macedonia is a significant country with natural and cultural tourists factors such as: mountains, caves, lakes, health resorts, wildlife, archeological sites, monuments, ethnographical heritage and gastronomy for developing cultural, recreation, spa, lake, rural, eco tourism and many more, but analyzing the statistics in 2013, the tourists arrival in Macedonia is 701.794, which is still far more less, $27.9 \%$ from 1990.

Table 1. Statistical review of the tourism in the Republic of Macedonia (1990 - 2013)

\begin{tabular}{|r|r|r|r|r|r|}
\hline Year & Tourists arrival & Tourist nights spent & Year & Tourists arrival & Tourist nights spent \\
\hline 1990 & 974.537 & 3.099 .508 & 2002 & 441.712 & 1.850 .384 \\
\hline 1991 & 710.278 & 2.740 .484 & 2003 & 483.151 & 2.006 .867 \\
\hline 1992 & 585.699 & 2.139 .631 & 2004 & 465.015 & 1.865 .434 \\
\hline 1993 & 647.728 & 2.706 .373 & 2005 & 509.706 & 1.970 .041 \\
\hline 1994 & 613.154 & 2.476 .998 & 2006 & 499.473 & 1.917 .395 \\
\hline 1995 & 503.837 & 1.804 .310 & 2007 & 536.212 & 2.019 .712 \\
\hline 1996 & 476.205 & 1.696 .930 & 2008 & 605.320 & 2.235 .520 \\
\hline 1997 & 451.871 & 1.587 .146 & 2009 & 587.770 & 2.101 .606 \\
\hline 1998 & 575.080 & 2.426 .461 & 2010 & 586.241 & 2.020 .217 \\
\hline 1999 & 549.630 & 2.313 .142 & 2011 & 647.568 & 2.173 .034 \\
\hline 2000 & 632.523 & 2.434 .639 & 2012 & 663.633 & 2.151 .692 \\
\hline 2001 & 333.308 & 1.254 .582 & 2013 & 701.794 & 2.157 .175 \\
\hline
\end{tabular}

Source: State Statistical Office. Tourism in the Republic of Macedonia 2009 - 2013, pp 11

From the Transport, tourism and other services' publications of the State Statistical Office, in 2013 the average number of nights spent by tourist was 3.07 days ${ }^{\text {[57] }}$, while in 2012 was 3.24 days by tourist ${ }^{[58]}$. This indicates that Republic of Macedonia is a transit destination, mainly because of the average number of nights spent by both domestic and foreign tourists.

Due to the inconstancy of the State Statistical Office publications, there is no data regarding the foreign tourists from 2009 until now, that was previously recorded confirms that tourists are considering Republic of Macedonia as a transit destination. This means,

\footnotetext{
${ }^{56}$ Tuntev, Z. Touristic destination. University "St. Kliment Ohridski" - Bitola, Faculty of tourism and hospitality, pp 122,2007

${ }^{57}$ Republic of Macedonia State Statistical Office. Tourism in the Republic of Macedonia 2009 - 2013, pp 46

${ }^{58}$ Republic of Macedonia State Statistical Office. Tourism in the Republic of Macedonia $2008-2012$, pp 46
} 
that Republic of Macedonia has many potentials for developing selective types of tourism, especially transit tourism.

Table 2. Index of the structure of foreign tourists according to type of stay

\begin{tabular}{|r|r|}
\hline Type of stay & $\mathbf{2 0 0 9}$ \\
\hline One - day visit & 12.02 \\
\hline Transit & 55.32 \\
\hline On temporary stay & 32.65 \\
\hline Total: & 100.00 \\
\hline
\end{tabular}

Source: State Statistical Office. Survey on foreign visitors at border crossings, pp. 12

As a selective type of tourism, transit tourism can also be placed on the tourist market as an offer to foreign tourists. Republic of Macedonia has been identified as a transit tourist destination through the years, but strategies have never been developed. And, from Table 2 , the research clearly shows that most of the foreign tourists can cross through his territory are transit tourists, but with the proper analysis of the potential characteristics for its development a potential rival to the other types of selective tourism for increasing the tourist income and influence in the gross domestic product from tourism with proper definition of transit tourism and analysis of who are the transit tourists and how can be place adequate offers and services.

\section{TOURISTIC - GEOGRAPHICAL LOCATION}

Analyzing the characteristics of developing tourism in Republic of Macedonia, her location has always been the first attribute, as well as for developing transit tourism. Therefore, with a total area of $25.713 \mathrm{~km}^{2}$ and almost 2 million residents, the touristic geographical location of the Republic of Macedonia represents a significant component for its touristic development. Its central geographical location on the European continent and immediate closeness towards the countries and regions which represent eminent dispersive with the world, are from greatest importance for her touristic development.

Although, the Republic of Macedonia is a relatively small country, in a touristic sense it's in a bigger advantage, because of the increased concentration and location of natural and cultural heritage of her territory. And, exactly her central Balkan location allows her, significant concentrations of tourists with interweaving of roads with local, regional, national and international significance and potential value of developing transit tourism. Since, Republic of Macedonia's borders has not gone out on a sea, she is representing a continental country, her importance from the South-European location is reflected directly through the closeness of Middle-Mediterranean location which today is one of the most frequent communication in the world.

Even though, the competitions regarding the tourism development on the Balkan Peninsula, are same countries located here, on the Mediterranean and the Alps region, the transitive as one most prominent functional mark, will allow the Republic of Macedonia to benefit from her specific location. 


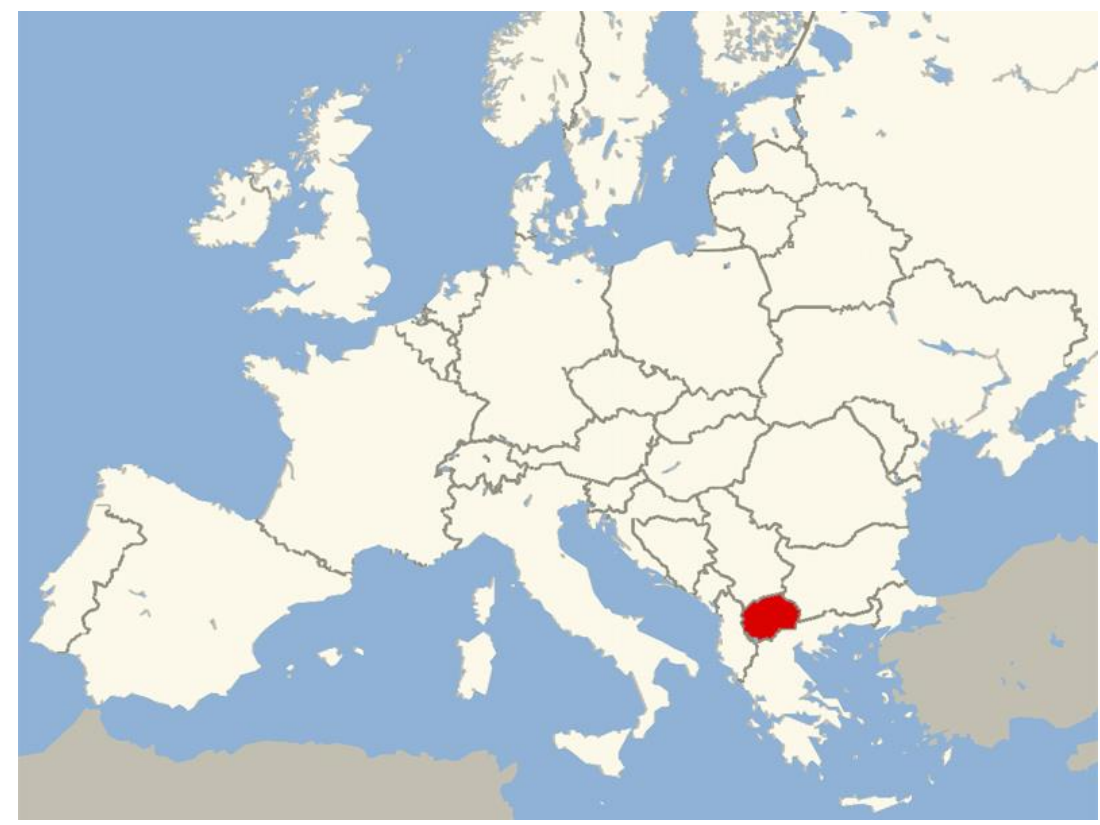

Image 1. Tourist - geographical location of the Republic of Macedonia

\section{TRANSITIVE AS FUNCTIONAL MARK}

Republic of Macedonia's tourist - geographical location is allowing her to be one of the countries with distinct functional marks. The transitive, primarily results from her central location at the Balkan and that indicates that in this area there are remarkable road directions with roots from antic roads such as "Via Egnatia" (east - west) and "Via Militaris" (north - south) ${ }^{[59]}$.

The transit road east - west, constructed by the Romans in the 2nd century BC allows bonding with of East-European and Asian countries with Adriatic shore, through Italy and with whole Southwestern Europe. The importance for the Republic of Macedonia on this road for her territory is because is passing right through Ohrid and Bitola.

The transit road north - south, an ancient Roman road build in the 1st century AD, today with a length of 924 kilometers is offering a bonding of North, Middle and West Europe with Southwestern Asia and Africa through the Suez canal and with Southeastern and South Asia.

Republic of Macedonia was always an intersection at the Balkan Peninsula, where mayor roads where intercrossing, and today's Pan-European Corridors VIII (east - west) and X (north and south), are leading rots exactly from the antic roads "Via Egnatia" (east - west) and "Via Militaris" (north - south), whereas most fastest, shortest roads they are connecting Europe and Asia through the Republic of Macedonia, leaving her the benefits from being a transit location.

\section{INTERDEPENDENCE AMONG TRAFFIC AND TRANSIT TOURISM}

Transit area is representing a location, such as the Republic of Macedonia, where the transfer of tourists on one relation is realized as domicile - tourist destination - domicile. Although, in the transit area in the research field of the tourism is established that is attracting least of all attention, unavoidable is the fact that the Republic of Macedonia with its location and critical road directions can benefit a lot from increasing the tourism

\footnotetext{
${ }^{59}$ Marinoski, N. Touristic geography. University “St. Kliment Ohridski” - Bitola, Faculty of tourism and hospitality, pp 185,2006
} 
income from this type of tourism. Having in mind, the interest for the construction of new road and railway corridor east - west, redevelopment and total reassertion of corridor north - south, with construction that is already in progress, the new road Demir Kapija Smokvica, Republic of Macedonia is in the lead by taking the part as the biggest traffic crossroad of the Balkan and Europe thanks to her transitive which in whole will additionally benefit the development of transit tourism.

Transit tourism is increasingly becoming a topic of interest in the plans of developing the tourism, because of its significance and influence to appear in every place available in the basic resource for transport, but as it is generally known that its development is capable at the main traffic crossroads and the immediate surroundings.

In accordance with the inevitable development of transit tourism is not to mention the influence of traffic and its wider development towards tourism. The resilience of road traffic towards the other types of traffic in transit tourism is shown by its accomplishments for stopping and enjoying in the tourist travel at every point of view. With this, road traffic will additionally expand its assistance in touristic income in particular tourist destination with continuous growth, because road traffic is the only branch in traffic that is constantly marking absolute and relative growth in the past decade from XXI century, as well as the number of carried passengers and the number of registered vehicles. Characteristic for the development of transit traffic in the Republic of Macedonia is exactly road traffic, thus if the point of development of traffic in the Republic is at a higher level of the economy will have a positive influence towards the possibility of developing transit tourism.

The dynamics, massive and distribution of transit touristic income caused the appearance of elastic consumption at this segment of tourist clientele. Consequently, transit roads are corridors with mobile touristic demand, whose offer is connected with several points, to which the equipment is fixed at the nearness of the roads. That kind of connected area is ensuring bigger economic effects from the offer and demand. Therefore, the basic sense of developing the transit tourism in the Republic of Macedonia is increasing the attraction along the roads, such as hotels, gas station, groceries. From thus establishing, where are forming an opinion that transit tourists have certain specific demands which will additionally complicate the forming of the proper touristic offer.

\section{DEVELOPING TRANSIT TOURISM}

Transit tourism is a concept that unavailable to find in a foreign tourist literature. In theory, this type of tourism is presented for the first time in the 60ties by the professor Ph.D. Srzan Markovik that worked on this question in the territory of Yugoslavia, and later in Croatia.

This concept is composed of two terms that are contrary by meaning. Transit means (journey from the place of beginning to the place of arriving) with the possibility of short delay, while Tourism means journey, residence and activities at the place of residence (destination) which will satisfy the touristic needs. All journeys are transitively though some areas, but transit is not a motive for travel. 


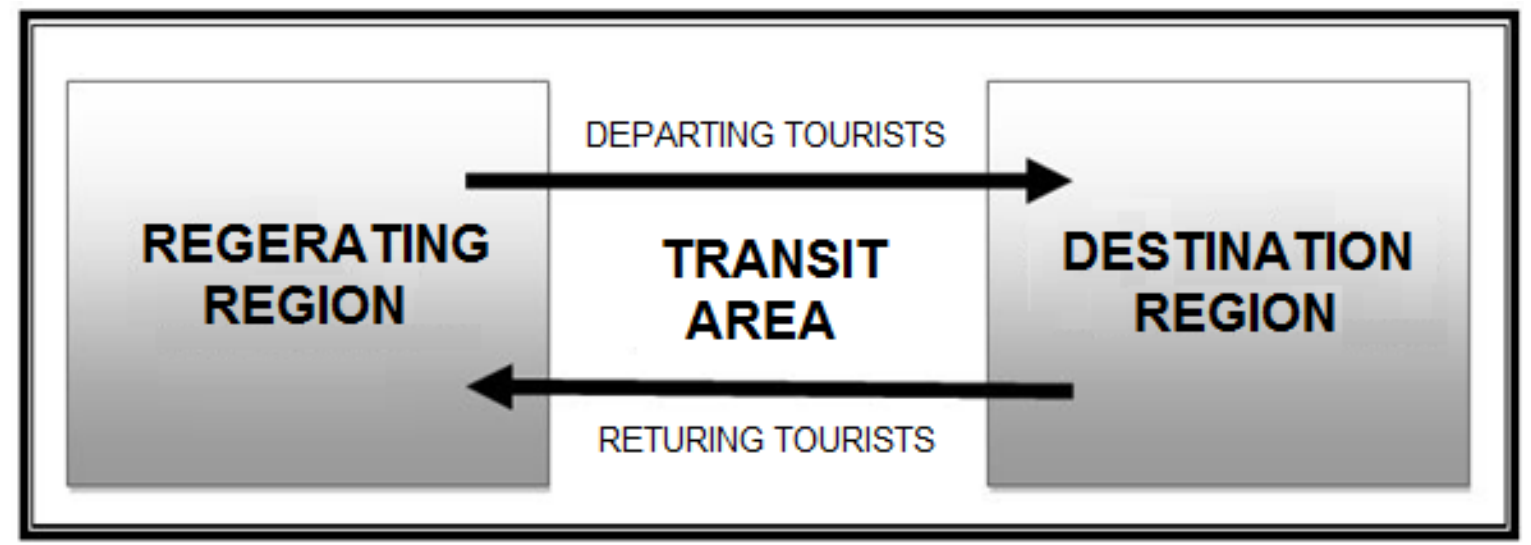

Image 2. Transit tourist system

In the contemporary literature, transit tourism is assumed to be a distinct design of the tourist activity. In the Republic of Macedonia transit tourism is outspread across the country as well in practice, but still there isn't a clear definition of what do we mean when we say transit tourism, theoretically and methodically.

Defining the term transit tourism, amount of relationship and appearance in involved a sophisticated reflection of all relevant factors in connection with the activities of tourists on certain touristic destination, where their stay is with certain purpose from a couple of minutes to one or two nights. Still, the time of stay of transit tourists will be defined by the quality of the offer with conspicuous tourist value. Nevertheless, the stay of transit tourists determinate the State Statistical Office in the Republic of Macedonia, where often because of the conspicuous touristic value in a certain place; transit tourism can even form type of excursion characteristics.

\section{WHO ARE THE TRANSIT TOURISTS?}

The definition of transit tourists is as well subjected to two concepts, concept where tourists are staying one day or spending one night in accommodation facilities, and a concept transit, which is related to that the mentioned tourists in a certain destination that spent a night, and it is not a goal of his travel. Today these kinds of passengers are assumed as tourists, because they've realized a night spent, but not necessarily in an accommodation facility from the hotel industry ${ }^{[60]}$. But, in Republic of Macedonia, according the State Statistical Office, the transit tourist is defined as persons who enter this country from one borderline and exit from another, with the purpose for extending and completing their travel in another country without spending the night in the country ${ }^{[61]}$.

Still, the needs of transit tourist because of the long time period travelling are fond of recreation and leisure which often contains an offer of accommodation for one night. In addition, this consumption from transit tourists additionally contributes to the development of the hotel, or other accommodation facility, their and tourist income.

At the territory of the Republic of Macedonia, from researching this field of transit tourism, we've come to understand that usually transit tourism arrives in the afternoon

\footnotetext{
${ }^{60}$ Kovacecic, T \& Obradovic, S. Is there a transit tourism in Serbia? - example municipality Subotica, Institution of geography, Magazine Tourism, num. 10, pp 40, 2001

${ }^{61}$ Republic of Macedonia State Statistical Office. Survey on foreign visitors at border crossings pp 6, 2009
} 
and leave in the morning in the accommodation facilities. Their offer consists of spending the night and breakfast. Any additional recreation or visit depends if we are describing a bus tour or a family travelling by car. Nevertheless, the needs are the same, and therefore without good promotion of the Republic of Macedonia a transit destination who offer appropriate hotel product or restaurant near by the highway, there isn't going to be a transit tourism. That is way, we've divide the needs of transit tourist into two categories: - Basic needs: access to fuel, food, water, first aid and garage mechanic, also a place for long or short leisure, like a hotel or a restaurant. While creating the offer for transit tourists, this type of needs are constant and do not accept any sort of change;

- Additional needs: variable type of needs, that depends from the habit of transit tourists, where for example, if they are organized bus tour with one night spent in the Republic of Macedonia, they offer mind include an offer for satisfying the need of discovering new places and languages, places and people, the need of tasting the local cuisine and gastronomy. Other additional needs might even include information for the roads, newspapers, books and souvenirs.

\section{CONCLUSION}

Republic of Macedonia is a country with impressive tourist - geographical location on the Balkan Peninsula as many of her own characteristics for the developing of many types of selective tourism. From ancient times until today mayor roads are still located here allowing her to benefit from them. With the possession of these key determinants, the development of transit tourism should be one of the primary focuses for the country. By defining and sorting the needs of transit tourists, various offers can be made through the main roads and corridors, to attract transit tourist and benefit from their consumption. Even though, is a short time period, the proper promotion and prepared program are capable of presenting the natural and cultural heritage and leave an impression. Because with the development of transit tourism and attracting transit tourists on the territory of the Republic of Macedonia and their motivation for stopping and spending the night in a hotel, will benefit for more intensive development of the other selective types of tourism in the Republic. 


\section{REFERENCES}

[1] Pančič Kombol, Tonka. Selective tourism. TMCP Sagena d.o.o Matulji, 2000

[2] Tuntev, Z. Possibility of development selective types of tourism in Republic of Macedonia. Institution of geography, Magazine Tourism, num. 5, pp 32, 2001

[3] Tuntev, Z. Touristic destination. University "St. Kliment Ohridski" - Bitola, Faculty of tourism and hospitality, pp 23, pp 122, 2007

[4] Republic of Macedonia State Statistical Office. Tourism in the Republic of Macedonia 2009 - 2013, pp 11, pp 46, 2014

[5] Republic of Macedonia State Statistical Office. Tourism in the Republic of Macedonia 2008 - 2012, pp 46, 2013

[6] Marinoski, N. Touristic geography. University "St. Kliment Ohridski” - Bitola, Faculty of tourism and hospitality, pp 185, 2006

[7] Kovacecic, T \& Obradovic, S. Is there a transit tourism in Serbia? - Example municipality Subotica, Institution of geography, Magazine Tourism, num. 10, pp 40, 2001 [8] Republic of Macedonia State Statistical Office. Survey on foreign visitors at border crossings pp. 6, pp 12, 2009

[9] Krakutovski, Z \& Todorovski, Lj. \& Mijoski, G. Recommendation for development of road and railway substructure in the Republic of Macedonia, Institution for economic strategies and international relations, pp 3, 2008

[10] Nestoroska, I, I. International tourism. University "St. Kliment Ohridski" - Bitola, Faculty of tourism and hospitality, pp 133-135, 2006

http://www.turizmologija.com/clanak/tranzitni-turizam/ 